\title{
The Sociolinguistics Study of Gender Address Patterns in the Hausa Society
}

\author{
Hajia Hauwa Salihu
}

\begin{abstract}
This paper looks at the choice, the shifts and the gender differential linguistics style of the use of names in a Hausa community. Social gender is an essential, stable category in the context of speech because it is perpetually (re) produced via language and communication. Addressing in Hausa society is influenced by the Cultural Revolution in Hausa land. The emphasis is on the discussion of the types of names the Hausas utilize, the context in which they are applied, the semantics, and the circumstance that motivated their creation, the addresser and the addressees relationship, the historical, cognitive, and ideological reality which determined the choice, the changes and the address variants.
\end{abstract}

Index Terms-Gender classification, naming patterns, relationships.

\section{INTRODUCTION}

Names show a relationship between language and society. [1] in Romeo and Juliet says: "What is a name? That which we call a rose by any other would smell as sweet". Rose is called rose because the society calls and accepts it as rose.People, objects, events, experiences, and feelings have a particular label or name solely because a community of people have arbitrarily decided to so name them. Names play vital roles in every society, they symbolize a man's social position in relation to the people around him and his status is readily recognized. Address forms according to [2][4]are socially driven phenomena, in other words they can mirror the complex social relations of individuals in a speech community. [5] Argue that "in different social context different terms of address will be used". Men and women use slightly different language styles.

The initial identification of women's register was by [6] he argued that thestyle of language served to maintain women's (inferior) role in the society "female deficit approach". A later refinement of this argument was that gender differences in language is reflecting a power difference ([7] "Dominance theory"). However, these perspectives have the language style of men as normative, impliedly, women's style as inferior. More recently [8], [9] has compared gender differences in language as more similar to 'cultural difference (Cultural difference approach). Comparing conversational goals, she argued that men have a report style, aiming to communicate factual information whereas women have a rapport style,more concerned with building and maintaining relationships. There are parts of address terms that are historically differentiated by sex

Manuscript received May 27, 2013; revised August 5, 2013.

Hajia Hauwa Salihu is with the Academic Planning Department, Kano State Polytechnic, Kano, Nigeria (e-mail: hasamud@gmail.com). alone, but which, overtime have gained different connotations (e.g., of status or values) and in some cases different denotations.

\section{Gender IN THE HAUSA AdDress Patterns}

In Hausa society name(s) given to a person is/are determined by the circumstances surrounding or prevailing at the time of its birth; certain features on the child, achievement in life and other characteristics. The name(s) is/are derived from a multiplicity of service, both modern and traditional; proper names, nicknames, titles, pronouns and prefixes are commonly used as they portray the cultural values and changes over time. Hausa language is witnessing a transition: the transformation of the conservative Hausa society in to a modern one. The instances of foreign and religious influence from other languages i.e. Instances in Shona language of Zimbabwe(African culture) and Persian language of Iran (Arab-Islamic culture) are typical examples prevailing in Hausa language sharing the same characteristics of being an African and an Islamic state (they tend to adopt Arab names, and eventually make them Hausanized).

Men's language as well as names in Hausa society differs from that of women and their roles are highly influenced and controlled by Islamic culture; their roles are predicted in separated an expectation which seems to determine their naming patterns and language use. In their interactional patterns, men and women in the Hausa society are believed to carry over their societal relationship of inequality; they maintain the normal 'power' relationship that exist in the society with men dominating and women being subservient. It may be reasonable to say that men and women behave like this because the process of socialization has taught them to assume different roles in the society.The culture of Hausa land is patriarchal and fundamentally oppressive through the mediation of family (a process by which a woman is silenced, unheard, because she is not supposed to be self-assertive).

"Gender is so pervasive that in a society we assume it is bred in our genes. Most people find it hard to believe that gender is constantly created and re-created out of human interaction, out of social life, and is the texture and order of that social life. Yet, gender, like culture, is a human production that depends on everyone constantly 'doing gender" [10].In [11] linguistics, a distinction is drawn between I-Language (Internal Language) the study of syntax and semantics in language and E-Language (External Language) applying to language in social contexts; i.e. behavioural habits shared by a community. The Hausa speech community has both the grammatical gender and the 
social gender. This study is primarily focused on the ELanguage (Language in social context).

Ref. [12] in his study of relationship among participants in Columbia, identified five categories of address terms: second-person pronouns, proper names, kinship terms, title, nicknames, and adjectival terms. While studying in Kannada language spoken in Mysore District in India [13], considered nine types of address terms as: caste name, names by which the exalted status of individuals are revealed or implied, personal names, kinship terms, professional term, and professional names for exaltation, personal name-kinship terms, professional term, personal names of professional terms, and non-respectable term. A more recent study from a neighbouring African country, Ghana, [14], [15] in Akan, classified eight categories that constituted the non-kinship linguistic repertoire used addressively by residents as personal names, titles, catch phrases (C.Ps) Zero address forms, descriptive phrases, attention getters, occupational terms, and pronouns.[16]-[18] respectively analyze the common Persian address terms in ten categories; the personal names, title terms, religious address terms, occupation-bound terms, kinship terms, honorific or terms of formality, endearment names, personal pronouns, description phrase, and zero address terms. Yet in another African categorization by [19] in his respective studies of the Shona language of Zimbabwe has seven categories: the first name (FN, LN, totems or praise names), nicknames, endearment names, adoptives, war names, zero terms and semantic extensions, and the pronoun of address.

Although, the categorization in the studies cited above demonstrate address forms of different languages and cultures, they show similarities as well as dissimilarities in the way the choice of linguistic signals affects different techniques to open, further maintain, or close conversations, and also accept variations in classifying address terms to represent cultural and social differences of the users. Earlier socio-linguistics studies of Hausa address terms by [20] and also [21] enumerated factors determining the choice of address terms in Hausa community: they are, natural factors such as age, sex and kinship, social factors such as marital status, socio-political power, wealth and education: factors related to the speech event like contextual factors, situational factors, friendship and intimacy, and the usage of particular pronouns. It is against this backdrop that this paper classified the Hausa address patterns under nine categories: personal names, titles, pronouns, descriptive phrases, endearment names, multiple names, kinship terms, adoptives, zero terms, and semantic extensions.

\section{A. The Personal Name (s)}

In the Hausa society, [20] stated that a child is given 'real personal name' at birth on the occasion of name giving, borrowed from Islamic and Arabic tradition. Addressing a person by name happen with the following possibilities:

- By first name (FN), e.g. Muhammad (male), Aisha (female)

- By middle name (MN), e.g. Auwal (male), Nana (female)

- By first and middle name (FN plus MN), e.g. Muhammad Auwal (male) Nana Aisha (female)

- By middle and last name (ML plus LN), e.g.

\section{AuwalAhmad (male) Nana Ibrahim (female)}

- By full formal name (FN, MN plus LN), e.g. Muhammad Auwal Ahmad (male) Aisha Nana Ibrahim (Female).

According to [20] "For the average Hausa person his full official name, is his first name plus one other name...the last name can be his father's name, his brother's name, his grandfather's name, name of a city, a town, a village of a particular area from which he came". Furthermore, [20] said that, as for women, a married woman's official name may be her first name plus her husband's first or last name or both, or maintain her father's name as her last name. The use of personal name(s) in Hausa society can be reciprocal and non-reciprocal as it is determined by age, social and occupational status, kinship, and attitudes. Usage is often underpinned by naming conventions.Acceptable cases FN calling may be limited to parents, elders, superiors, colleagues, and peers to their siblings, juniors, subordinates, and the like, or in very formal settings with observable status differences like schools, offices etc, for instance, a teacher or senior officer may call his student or junior staff by full name. This is a one-way traffic; the subordinate cannot call the superior by his first or full name. But, shifts and sometimes short-term switching occur when there are instances of attitudinal changes. For example, normally there would be asymmetrical relationship between a superior and his subordinate, but when the degree of formality lesson; they will start addressing each other with first name, perhaps in secret to start with, shift here is interpreted as changing the listener's perceived relation to the speaker same as the Shona in Zimbabwe.

\section{B. Title}

The gender specific titles that Hausa male and female speaker's use may be a religious title, a professional/occupational title, a traditional title, or both.One may be addressed by a general title (GT) only, general title plus first name (GT plus FN) general title (GT) plus full official name $(\mathrm{FN})$ as in:

\section{1) The religious title}

one particular way of addressing those that have been on pilgrimage to the holy land Mecca is by:

- General title (GT), Alhaji for males, Hajiya for female or

- General title (GT) plus first name (FN), i.e. Alhaji Musa (male) HajiyaAmina (female) or

- General title (GT) plus full official name (FN), i.e. Alhaji Musa Isa (male) HajiyaAminaAliyu (female)

- Other general titles (GT) as in:

$$
\begin{gathered}
\text { Mallam(male),Malama(female) } \\
\text { Ustaz (male), } \quad \text { Ustaziya (female) } \\
\text { Sharif (male), } \\
\text { Sharifiya (female) } \\
\text { Yasayyadi (male) yasayyada (female) }
\end{gathered}
$$

Other religious terms that have no female equivalent due to the influence of Islamic religious orientation and political system they may include: terms like Alaramma, Halifa, Liman/Imam, Sheikh, Wali and the like. This is similar to the Persian classification.

\section{2) The professional/occupational title}

In Hausa society, professional titles are as many as the 
occupations themselves. There is a detailed explanation in [20], [21], only the gender-specific classification is left out, and this is the primary concern of this study. Therefore, one could generally address his or her recipient by such terms as: Dokta (Dr), Furofesa (professor), Gwamna (Governor) Sanata (Senator), Onarable (Honourable), Minista (Minister) Manaja (Manager) Opisa (Officer). Terms like kwaminishina (Commissioner male), kwaminishiya (Commissioner female), Sakatare (secretary male, sakatariya (Secretary female) are gender-specific. These terms can be used in isolation or with or without first name $(\mathrm{FN})$, middle name $(\mathrm{MN})$, last name $(\mathrm{LN})$ or full formal name (FN) depending on the individual, the circumstances and the degree of familiarity. An interesting feature in Hausa language similar to that or Persian language is this idea of reversal of job title from the initial position to the last position, for instance, instead of (T plus FN) as in driver Ahmadu, carpenter Musa or mechanic Isa, they are conventionally and conveniently addressed as Ahmadudreba (driver) Musa Kafinta (carpenter) or Isa Makanike (mechanic). Perhaps different styles are used while addressing same occupation to reveal their degree of respect or to make them-selves superior, equal or inferior in relation to the addressee.

\section{3) The traditional title}

There are numerous types of traditional expressions used to dignify or honour the addressed person. In [20] "such terms convey honour, social superiority, official, patronage and the like". Also, such terms may be used in several forms, before, with or without the name of the addressee. The gender-specific terms are: e.g., Sarki (male), Sarauniya (female) Gimba (male), Gimbiya (female) Maigida (male) Uwargida (female). But, such terms as waziri, chiroma, sardauna, galadima, and the like are only male inclined there is no female equivalent for them. For example:

Title, first name plus last name (T, FN plus $\mathrm{LN})$ as in SarkiAbdullahiBayero (male) SarauniyaAminaAliyu (female). Most of these titles are used in isolation, however, they can be used with or without first name, middle name, or full formal name.

\section{The kinship termsFigures}

Because there are several members of each kin category, kin terms in Hausa family domains are used as a form of title; they are used with the first name in particular reference. Quite a number of these kin terms indicate the family relationship among individuals. Hausa language share some similarities with Shona language of Zimbabwe and Persian language of Iran. Accordinglythe classification is thus:

- Father may be called Baba, Abba, Maigida, 'Alhaji', Mallam

- Mother may be called Bābā, Umma, Ummi, Mama, Iya, Inna, Gwaggo, 'Hajiya, ' etc

- Brothers are called Yaya, 'Alhaji' 'Mallam', by their first name (FN), and also by the title plus first name (TFN)

- Sisters are called Yaya, Ya, plus the first name, 'Hajiya' by first name (FN), and also title plus the first name (TFN)

It should be noted that Hausa speakers have different names for uncles and aunts from each side (father and mother). Thus, ones paternal uncle is called 'Baffa'Baba', while maternal uncle is called ' $K a w u$ ', most of the times called with the first name in direct address or in reference.Aunts i.e., father's sister is called Baba while mother's senior sisters are called 'Yadikko' and junior sisters are called 'Yakumbo', Nene,' 'Inna'. Grandparents are usually addressed by heir title, title plus first name (TFN) or any of their referent name, Parents-in-laws are usually addressed by the names their children call them. In some instances daughters-in-law i.e. son's wife and/or the last/most recent in the house wifeis addressed 'Amarya' (bride).Reverse addressing is peculiar with Hausa speakers. Thus a child named after a grand parents name can be addressed Baba, Abba, DattijoWalid, for male children and Māmā, Ummi, Walida,Umma (mother) by their parents.

\section{The Endearment Terms}

Addressing sometimes takes an emotional tone; addresses are called with a friendlier, more passionate and more amiable tone. The intimacy is marked either by tone or by the contraction of the names. Nicknames, pet names, contracted short forms, and alternate forms can fall under this category.

The contracted forms: The classification came up with the ways short forms are formed through the process of dropping the first or last syllables) of the first name (FN). "Polysyllabic names became disyllabic after the process has taken place" [20]. They can be formed by Table I-III.

TABLE I: DROPPING THE LAST SYLLABLE (S) OF THE BASIC FORM, FOR EXAMPLE

\begin{tabular}{|l|l|l|}
\hline Basic forms & Sex & Shortened forms \\
\hline Abubakar & M & Abu \\
\hline Adam & M & Ado \\
\hline Ibrahim & M & Ibro, Iro \\
\hline Maryam & F & Mairo \\
\hline Sa'adatu & F & Sa'a \\
\hline Hadiza & F & Dija, Dije \\
\hline
\end{tabular}

TABLE II: DROPPING THE FIRST SYLLABLE (S) OF THE BASIC FORM, FOR

\begin{tabular}{|l|l|l|}
\hline Basic forms & Sex & Shortened forms \\
\hline Abubakar & M & Bubakar \\
\hline Ahmadu, Amadu & M & Madu \\
\hline Usmanu & M & Manu \\
\hline Asma'u & F & Ma'u \\
\hline Zainab & F & Abu \\
\hline
\end{tabular}

TABLE III: CHANGING A CONSONANT OR A VOWEL IN THE ROOT OF THE BASIC FORM OR DROPPING THE CONSONANT TOTALLY, FOR EXAMPLE

\begin{tabular}{|l|l|l|}
\hline Basic forms & Sex & Shortened forms \\
\hline Abubakar & M & Habu \\
\hline Auwalu & M & Lawan \\
\hline Hadiza & F & Dije \\
\hline Maryamu & F & Mamu \\
\hline
\end{tabular}

\section{E. The Nicknames}

Nicknames are either given to individuals or they adopt for themselves. Nicknaming is a very popular characteristic of most African languages. The self-selected nicknames have a positive connotation, the imposed nicknames suffers resistance and are often maintained in secrete. Positive nicknames are symbols of endearment and great achievement; they may be used at all levels and by everyone. For example: Mai Nasara (male, female- successful one), Zaki 'lion' (male- brave one), Damo "land monitor lizard' 
(male- patient and kind one), Tunkiya 'sheep' (femalepatient and kind one). Some positive nicknames are derived from people's professions i.e. Dokta, (Dr) Injiniya (engineer) etc. for instance a teacher is given a nickname by pupils or students from repeated use of certain terminology, marked pronunciation, dressing, and certain mannerisms and/or from physical appearance. Such nicknames are often hierarchical. Usually, negative nickname are deriding, insulting, unacceptable and upsetting to the addresses, sometimes known and sometimes unknown to the addressee. For example: Aku 'Parrot' (male, female- talkative person) Bera 'Mouse' (male- habitual thief) Gafiya 'Bandicoot' (female- thief) e.t.c.

\section{F. The Alternative Forms}

Ref. [20] Said "These nicknames are semantically formed by substituting a name with another name or phrase which is phonologically totally unrelated to the basic names", for example (See Table IV):

TABLE IV:NAMES FORMED BY SUBSTITUTION

\begin{tabular}{|l|l|l|}
\hline Basic forms & Sex & $\begin{array}{l}\text { Alternate } \\
\text { forms }\end{array}$ \\
\hline Muhammad & M & Dan-Amina \\
\hline Adamu & M & KakanTalikai \\
\hline Aliyu, Ali & M & Haidara/JanZaki \\
\hline Fadimatu & F & $\begin{array}{l}\text { Bintu, Fati, } \\
\text { Tarasulu }\end{array}$ \\
\hline Halimatu & F & Dubu \\
\hline Bilkisu & F & Maigado \\
\hline
\end{tabular}

\section{G. The Descriptive Terms and Phrase}

In Hausa society, a lot of nicknames were highly descriptive and imaginative they refer to the addressee's distinctive stature. [20] Had identified different categories of descriptive terms. Thus, there are names (See Table VXIII):

TABLE V: NAMES REFERRING TO ACTUAL DAY WHEN A CHILD WAS

\begin{tabular}{|l|l|l|}
\hline Male & Female & Day \\
\hline Danjuma & Juma & Friday \\
\hline Danjummai & Jummai & Friday \\
\hline Najume & Tajume & Friday \\
\hline Dan'asabe & Asabe & Saturday \\
\hline DanladiLadi, & Ladidi & Sunday \\
\hline
\end{tabular}

TABLE VI:NAMES INDICATING UNUSUAL FEATURES, FOR EXAMPLE

\begin{tabular}{|l|l|l|}
\hline Male & Female & Gloss \\
\hline Bebe & Bebiya & Deaf, mute \\
\hline Kuturu & Kuturwa & Leper \\
\hline Makaho & Makauniya & Blind, etc \\
\hline
\end{tabular}

TABLE VII: NAMES GIVEN TO PERSONS WITH CERTAIN QUALITIES OR ATTRIBUTES, FOR EXAMPLE

\begin{tabular}{|l|l|l|}
\hline \multicolumn{2}{|c|}{ ATTRIBUTES, FOR EXAMPLE } \\
\hline Mashi & Female & Gloss \\
\hline Hakurau & Goshi & $\begin{array}{l}\text { Someone whose arrival } \\
\text { brings } \\
\text { fortuneandhappiness }\end{array}$ \\
\hline Maye & Mayya & The patient one \\
\hline
\end{tabular}

TABLE VIII: NAMES GIVEN IN FORM OF PHRASES, FOR EXAMPLE

\begin{tabular}{|l|l|l|}
\hline Mai & sunan & Maza \\
\hline Mai & sunan & Bappa \\
\hline Mai & sunan & Umma, e.t.c \\
\hline
\end{tabular}

TABLE IX: NAMES INDICATING INFANTS BORN IN AN UNUSUAL WAY, FOR EXAMPLE

\begin{tabular}{|l|l|l|}
\hline Male & Female & Gloss \\
\hline Mairiga & Mairiga & Born in a cool \\
\hline Mantau & Mantai & The forgotten one \\
\hline Shekarau & Shekarau & $\begin{array}{l}\text { A child staying for one or } \\
\text { more years in the womb }\end{array}$ \\
\hline
\end{tabular}

TABLE X: NAMES DONATING HOPE OR PRAYER BY PARENTS FOR A CHILD TO SERVICE, FOR EXAMPLE

\begin{tabular}{|l|l|l|}
\hline Male & Female & Gloss \\
\hline Dogara & Dogara & Depending on Allah \\
\hline Kyauta & Kyauta & Allah's gift \\
\hline Nabara & Nabara & May the baby be spared \\
\hline
\end{tabular}

TABLE XI: NAMES INDICATING THE YEAR, SEASON THE CHILD WAS BORN, FOR EXAMPLE

\begin{tabular}{|l|l|l|}
\hline Male & Female & Gloss \\
\hline Dan'azumi & Azumi & Born during Ramadan \\
\hline Sallau & Tasallah & $\begin{array}{l}\text { Born on the day of Id-el- } \\
\text { Fitr }\end{array}$ \\
\hline Wada & Yalwa & $\begin{array}{l}\text { Born when the parents had } \\
\text { abundant wealth }\end{array}$ \\
\hline
\end{tabular}

TABLE XII: INDICATING AN INDIVIDUAL TRIBE, AREA OR BORN OR TOWN, FOR EXAMPLE

\begin{tabular}{|l|l|l|}
\hline Male & Female & Gloss \\
\hline Banufe & Banufiya & Nufe person \\
\hline Dan Kano & 'Yar Kano & Kano person \\
\hline Dan Fage & 'YarFage & Personfrom Fage area e.t.c \\
\hline
\end{tabular}

TABLE XIII: GIVEN TO CREATE DIMINUTIVE FORMS WITH OR WITHOUT ADDING THE SUFFIX DAN 'SON OF OR YAR 'DAUGHTER OF' TO COINED NAMES, FOR EXAMPLE:

\begin{tabular}{|l|l|l|}
\hline Male & Female & Gloss \\
\hline Danmitsitsi & 'Yarmitsila & Tiny person \\
\hline Danyaro & 'Yaryarinya & Small or tinychild \\
\hline Ciriri & Ciririya & $\begin{array}{l}\text { A small tiny person } \\
\text { e.t.c. }\end{array}$ \\
\hline
\end{tabular}

\section{H. The Adoptive}

One of the consequences of Islamic religion in the naming pattern in Hausa society is the adoptive. Most of these names are "meaningful Arabic words which were not previously used by the community. Examples are Faiza 'the winner' Jamilu 'the beautiful one', Mubarak 'the blessed one', Taufik 'the lucky one', for males. And for females: Jamila, Faiza, farida 'the only one' Naima, Zahra, 'the flower', etc. in [20]. Any of these names can be used as a first name, full official name and pet name.

\section{The Multiple Names}

A Muslim Hausa child can have one or more names as the first name (FN). The names are religiously inclined and mostly given to male children as full official names. For example: Muhammad Mukhtar, Muhammad Auwal, Muhammad Kamaluddeen, Abdulrahman, Abdu-'aziz, Abdul-Kadir, e.t.c. As for females we can have Halimatus 
Sa'adiyya, Rabi'atu Nabawiyya, Fadimatu Zahara'u, Hadizatul Kubra, etc.

\section{J. Zero Terms and Semantic Extensions}

In the Hausa community, 'name avoidance' still plays an important role both in "focused and unfocused interaction" in [20]. There are certain people whose names are not supposed to be mentioned, some names are unknown to the addresser while some addressers are in doubt. Employment of attention getter's and semantic extension saves this dilemma. [20] said "The kin terms dan nan 'this son' dana 'my son', 'yar nan' 'this daughter', 'yata 'my daughter' are used to address someone the same age as the addresser's own son or daughter. Dan uwa 'brother', yar'uwa 'sister' are used to address a person whose name the speaker does not know and who is the same age as the speaker. The termyāyańa 'my senior brother' or yāyāta 'my senior sister' is used to address someone older than the speaker, while кanina 'my junior brother' or kanwata 'my junior sister' is used to address someone younger. "It is also a common practice by Hausa's to address people old enough to be their parents with $b \bar{a} b \bar{a}$ 'father', kawu 'uncle', inna 'mother', $b \bar{a} b \bar{a}$ 'mother', etc. In essence, some words with an already established were meaning acquire new senses and extension.

\section{$K$. The Pronouns of Address}

According to [20] "In Hausa, the pronouns also identify the participant's social or interpersonal social relations". Hausa he said, has only one level of second person pronouns.

TABLE XIV: SECOND PERSON PRONOUNS

\begin{tabular}{|l|l|}
\hline Kai $2^{\text {nd }}$ & person masculine singular \\
\hline Ke $2^{\text {nd }}$ & person feminine singular \\
\hline Ku $2^{\text {nd }}$ & person plural \\
\hline
\end{tabular}

The distinction between familiar and formal ([22]tu/usted Spanishty/yy: Russian) does not exist in Hausa. However, Hausa does have an impersonal aspect pronoun 'a 'which functions very much as a formal and specific form. He went further to explain the use of possessive singular or plural pronoun as a linguistic signal of authority or lack of it in reference to the speaker the addressee or the person referred to".

TABLE XV: EXAMPLES OF SHORT FORMS SUFFIXED POSSESSIVE

\begin{tabular}{|l|l|l|l|}
\hline Singular & Example & Plural & Example \\
\hline $\begin{array}{l}\text { Na (male, } \\
\text { female) }\end{array}$ & $\begin{array}{l}\text { Littafina } \\
\text { 'my book' }\end{array}$ & $\mathrm{Mu}$ & $\begin{array}{l}\text { Littafinmu 'our } \\
\text { book }\end{array}$ \\
\hline $\begin{array}{l}\mathrm{Ta} \\
\text { (female) }\end{array}$ & $\begin{array}{l}\text { Rigata 'my } \\
\text { dress' }\end{array}$ & $\mathrm{Ku}$ & $\begin{array}{l}\text { Rigarku'your } \\
\text { dress }\end{array}$ \\
\hline $\mathrm{Ka}$ (male) & $\begin{array}{l}\text { Wandonka } \\
\text { 'his trouser' }\end{array}$ & $\mathrm{ku}$ & $\begin{array}{l}\text { Wandonku'their } \\
\text { trouser' }\end{array}$ \\
\hline $\begin{array}{l}\mathrm{Ki} \\
\text { (female) }\end{array}$ & $\begin{array}{l}\text { Gidanki } \\
\text { 'her house' }\end{array}$ & $\mathrm{Ku}$ & $\begin{array}{l}\text { Gidanku'your } \\
\text { house' }\end{array}$ \\
\hline Sa (male) & $\begin{array}{l}\text { Mukullinsa } \\
\text { 'his key' }\end{array}$ & $\mathrm{su}$ & $\begin{array}{l}\text { mukullinsu'their } \\
\text { key' }\end{array}$ \\
\hline $\begin{array}{l}\text { Ta } \\
\text { (female) }\end{array}$ & $\begin{array}{l}\text { Jakarta 'her } \\
\text { bag' }\end{array}$ & $\mathrm{su}$ & $\begin{array}{l}\text { jakarsuF'their } \\
\text { bag' }\end{array}$ \\
\hline
\end{tabular}

Examples of long forms: Independent possessive; Still [20] said "In a Hausa society, one has to use the plural possessive pronoun, - $m u,-k u$ in order to indicate one's lack of authority. On the other hand, the speaker's use of the singular possessive, e.g., - na, - ta, - ka, - ki; nawa, tawa, naka, taki, indicate absolute control and authority over whatever he is referring to". Plural pronouns are enjoyed between certain categories of actual and potential relatives. Parents normally return plural forms to their adult children, particularly married ones. Reciprocal plural is also enjoyed between parent - in - laws and children - in - laws and adults of adjacent generations. Non reciprocity is determined by the speaker's status, age, role relationships

TABLE XVI: EXAMPLES OF POSSESSIVE PRONOUNS

\begin{tabular}{|l|l|}
\hline Singular & Plural \\
\hline $\begin{array}{l}\text { Nawa (male, female) } \\
\text { 'mine' }\end{array}$ & Namu (male) ‘ours' \\
\hline $\begin{array}{l}\text { Tawa (male, female) } \\
\text { 'mine' }\end{array}$ & Tamu (female) ‘ours' \\
\hline Naka (male) ‘yours' & Naku (make) ‘yours' \\
\hline Taka (male) ‘yours' & Taku (female) ‘yours' \\
\hline Naki (female) 'yours' & Nasu (male) 'theirs' \\
\hline Taki (female) 'yours' & Tasu(female) 'theirs' \\
\hline Nasa (male) 'his' & \\
\hline Tasa (male) 'his' & \\
\hline Nata (female) ‘hers' & \\
\hline Tata (female) 'hers' & \\
\hline
\end{tabular}

\section{CONCLUSION}

Like in many communities, the addressing status structure of the Hausa society consists of symmetrical and asymmetrical relationship and styles of interaction. In faceto-face interactions, the continuous creation, recreation, and maintenance of these kinds of relationships is largely achieved verbally through the choice of nouns and pronouns. The overlap of social conventions and grammatical rules is what accounts for the link between language and society. Every social distinction that is possible between speakers, the recognition and the display of which is necessary to the smooth development of an encounter, is overtly expressed in language choice. Each category of address term has its special usage for particular people and under certain conditions. The abundance and the frequency of the application of honorifics and titles in Hausa language revealed the importance of superiority and courtesy. It sounds that a superior, courteous and humble interaction is a striking feature of Hausa address system.

Another distinctive feature of Hausa language is revealed in the use of kinship address terms. Hausa is found to be very dependent on the family relations; this is specifically notable in reverse addressing or using kinships terms for a non-relative. Restrictions in the use of personal names of and pronominal on one hand and the tendency to use general, occupation titles, honorifics, and terms of formality makes the sense of formality a sticking feature of Hausa culture, language and address terms in particular. Hausa interlocutors are likely to make use of different techniques of addressing; these varieties provide the speakers with an extensive range of terms to address the recipients. Employment of a proper address term is affected by factors as age, gender, personality, social status, religious orientation, and family relationship, degree of respect, 
familiarity, formality, and intimacy between the interlocutors. Therefore, it is not enough just to have grammatical competency, one should learn where he belongs within them and know how language is used in the society.

This paper supported the view that language is sensitive to its social context. Any given instance of language is inextricably bound up with its context of situation. Simply presenting the learner with linguistic input will not guarantee that he will be able to express himself appropriately in different situation, he should be taught when to say what to whom and how. We need to know the sociolinguistic rules, that is, rules of appropriateness, not just rules of grammatical accuracy. As [23] points out, "the language learners needs to be able to handle language which is not idealize, rather language in use". The analysis of the address terms provided in this paper makes it clear that Hausa address terms are gender sensitive, relatively formal, culturally, socially, and politically loaded.

The paper has attempted to provide a framework for viewing to the topic, because its' sociolinguistic nature is yet to receive the extensive study that this fascinating topic deserves, further research seems to be required in such areas as:

- to explore the conditions under which different categories of address terms are used,

- to determine factors affecting the use of particular terms at the detriment of others,

- to explain the reasons for choosing one or the other address term; can be new ground for further research and studies.

\section{ACKNOWLEDGMENT}

My profound gratitude to God,to the Rector and my Director in my institution, is grateful for the encouragement and support. And to my family, their love, prayers, valuable time and understanding. I thank them all.

\section{REFERENCES}

[1] W. Shakespeare, Romeo and Juliet, Lindaka, 1597.

[2] E. Chaika, Language the Social Mirror, Rowley, MA: Newbury House, 1982.

[3] G. B. Paulston, "Pronouns of address in Swedish Class Semantics and a Changing System," Language in Society, pp. 5, 1976.

[4] P. Trudgill, Sociolinguistics: An Introduction to Language and Society, $4^{\text {th }}$ Ed. London: Penguin Books, 2000.

[5] G. B. G. Yule, Discourse analysis, Cambridge: Cambridge University Press, 1989, pp. 54.

[6] R. Lakoff, "Language and Women's place in Language in Society," Language and Woman's Place, vol. 2, pp. 45-80, 1973.

[7] W. M. O'Barr and K. A. Bauan, "Women's language or powerless language," in M. Ginetet al. ed., Women and Languages in Literature an Society, New York: pp.9-110.

[8] D. Tannen, "You don't understand," Women and Men in Conversation, New York: Williams Marrow, 2007.
[9] D. Tannen, "Women and men in conversation from you just don't understand," in E. Disched., Reconstructing Genders $4^{\text {th }}$ ed., Boston: McGraw Hill, 1990.

[10] D. Zimmermann and W. Candice, "Sex role interruption and silence in conversation," in J. Gumperz, 1982 ed., Language and Social Identity: A Cultural Approach to Male and Female Miscommunication, Cambridge: Cambridge University Press, 1975.

[11] N. Chomsky, Language and Mind, USA: Harcourt Race Jovanovich, Inc, 1972.

[12] K. L. Fitch, Speaking Relatively, Culture, Commission, and Interpersonal Connection, New York, 1998.

[13] L. Manjulaski. (2004). Modes of address in kannada: A sociolinguistic study of language use in Mysore district. [Online]. Available:

http://wwwlanguageinindia.com/sep2004/manjulaskshitermsofaddres $\mathrm{s} / \mathrm{html}$.

[14] J. B. A. Afful, "Address terms among university student in Ghana: A case study," Journal of language and intercultural communication, vol .6/1, pp. 7691, 2006a.

[15] J. B. A. Afful, "Non-kinship address terms in Akin: A Sociolinguistic Study of Language use in Ghana,"Journal of Multilingual and Multicultural Development, vol. 27/4: 275289, 2006b.

[16] M. I. Aliakbariand T. Arman. (2008).Therealization of address terms in modern Persian in Iran: A sociolinguistic study. [online] Available: http//www.linguinstic-de/35-08/aliakbari.Html.

[17] M. H. Keshavarz, "Forms of address in Post-Revolutionary Iranian Persian," A Sociolinguistic Analysis in Language in Society, vol. 17:565575, 1988, pp. 565-575.

[18] M. H. Keshavarz. (2010). Therole of social context, intimacy and distance in the choice of forms of address. [Online]. Available:http://iranian linguistics.

[19] P. Mashiri. (1999). Terms of Address in Shona: A Sociolinguistic Approach. [Online]. Available: http://archive lib. M.S.U edu/DMC/African \% 20 Journals/pdfs/ Journals \% 20 of $\% 20$ Zimbabwe /vo/ 26nl/Juz 026001007 pdf

[20] H. A. Daba, "Sociolinguistic study of address terms in Hausa," Ph.D. dissertation, University of Wisconsin, Madison, 1987.

[21] M. A. Kamal, "A Sociolinguistic analysis of Hausa patterns of address," M.A thesis, Bayero University, Kano, 1987.

[22] R. Brown and A. Gilman, "The pronouns of power and solidarity,"in Sebeoki. Thomas A. ed., Style in Language. Cambridge, M. A. 1960, pp. 253-276.

[23] G. Cook, Discourse, Oxford: University Press, 1990.

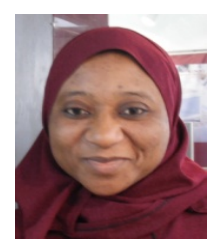

Hajia Hauwa Salihu was born in Kano, Nigeria on July 17, 1965. She holds a master's degree in English Language in 2011 and an MBA (master's degree in business administration) in 2005 all from BUK (Bayero University, Kano). Anaspiring,potential PhD candidate.

Since 1993, She has been a lecturer /coordinator english first with the department of General Studies, School of Technology, and later years with the School for General Studies .She was at a point in time an external moderator, HussainiAdamu Polytechnic, Kazaure, Jigawa, Nigeria. Until recently she is appointed the Coordinator Academic Support Services at the academic planning department, Kano State Polytechnic. She is actively into publications in journals and interested in the exploration of language and communication. Specifically, the relationship of language and social interaction.

Mrs Hauwa is currently a Member of the Linguistics Association of Nigeria (LAN), Member, National Association of Teachers of English of Colleges of Education and Polytechnics (NATECEP), Member, English Language Teachers Association of Nigeria, Kano Chapter (ELTA), Member, Women in Technical Education (WITED). She has received a scholarship from her institution for her Master's degree and recently nominated for the PhD scholarship award. 